\title{
MANAGERIAL OPPORTUNISM AND FOREIGN LISTING: SOME DIRECT EVIDENCE
}

\author{
AMIR N. LICHT* \\ 1. INTRODUCTION
}

To what extent do private interests of managers, controlling shareholders, and other insiders affect corporate actions and the structure of the legal system? This Article presents evidence that such interests (hereinafter "managerial opportunism," for brevity) have a significant effect on both aspects in the growingly important context of foreign listing.

Modern analyses of the corporate form invariably revolve around the agency problem,1 and "corporate governance" is widely understood today to constitute the means for coping with this problem. 2 Shleifer and Vishny, for instance, provide a thorough review of the theoretical and empirical literature on the relations between corporate governance and the agency problem. ${ }^{3}$ In particular, they discuss the interplay between legal rules and shareholding structures as alternative means for curbing adverse

* Lecturer, Interdisciplinary Center Herzliya, Israel. S.J.D., Harvard Law School; B.A. (Economics), Tel Aviv University; LLB., Tel Aviv University. For helpful comments I would like to thank: Bernard Black, Haim Falk, Howell Jackson, Nathan Joseph, Roberta Romano, Alan Schwartz, participants of the conference "Protecting Investors in the Global Economy," Tel Aviv University, June 2728,2000 , and the Journal's Editorial Team. The Author served as outside consultant during the later stages of the Israeli dual listing project. The opinions expressed here and errors are mine alone.

All translations are by the author and verified by the University of Pentsylomin Joumal of International Economic Low.

1 See Armen A. Alchian \& Harold Demsetz, Production, Informution Costs, and Economic Organization, 62 AM. ECON. REv. 777 (1972); Michael C Jensen \& William H. Meckling, Theory of the Firm: Managerinl Behtroior, Agency Costs and Oumership Structure, 3 J. FIN. ECON. 305 (1976).

2 See Andrei Shleifer \& Robert W. Vishny, A Strvey of Corpornte Governance, 52 J. FiN. 737, 738 (1997).

3 Id. ("Our perspective on corporate governance is a straightforward agency perspective."). 
effects of the agency problem. ${ }^{4}$ Direct evidence as to the incidence of the agency problem in particular situations (except for litigated cases of self-dealing, etc.) is relatively rare, however.

A prominent manifestation of the globalization of equity markets is the growing number of foreign listings, i.e., listings of stocks on markets outside the issuer's home country, which is usually its country of incorporation. 5 Academic interest in foreign listings is growing in parallel. In an extension of this literature, scholars recently started floating the idea that companies may want to list their stocks on foreign markets with a view to improve their corporate governance, thereby creating shareholder value. ${ }^{6}$ By doing so, issuers could metaphorically piggyback the host country's legal infrastructure. ${ }^{7}$ The debate over the feasibility and desirability of this "piggybacking paradigm" may be viewed, in turn, as an offspring of the broader debate over international regulatory competition in securities regulation. ${ }^{8}$

This Article argues that such piggybacking may also have a dark side in the sense that foreign listing transactions could be guided, inter alia, by managerial opportunism. Elsewhere I developed such an argument more by way of intelligent speculation.9

4 See id.

5 See International Federation of Stock Exchanges, http://www.fibv.com/ statistics.asp (last visited Mar. 24, 2001).

6 See John C Coffee, The Future as History: The Prospects for Global Convergence in Corporate Governance and Its Implications, 93 Nw. U. L. REV. 641, 674 (1999);

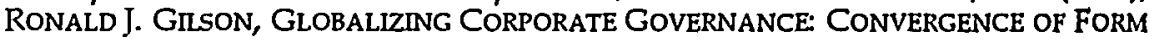
OR FUNCTION 26 (Columbia Law School Working Paper No. 174 \& Stanford Law School Working Paper No. 192, 2000), available at http://papers.ssrn.com/sol3 / papers.cfm?cfid=79829\&cftoken $=42986856$ \&abstract_id=229517 (last visited Mar. 24, 2001); Edward Rock, Securities Regulation as Lobster Trap: A Credible Commitment Theory of Mandatory Disclosure 10, (February 27, 2001) (unpublished working paper, on file with author).

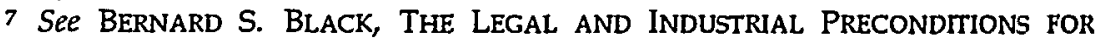
Strong Stock Markets, (Stanford Law School Working Paper No. 179, 2001), available at http://papers.ssrn.com/sol3/papers.cfm?cfid=79829\&cftoken $=429868$ $56 \&$ abstract_id=182169 (last visited Mar. 24, 2001).

8 See, e.g., Roberta Romano, Empowering Investors: A Market Approach to Securities Regulation, 107 Y ALE L.J. 2359 (1998) (advocating regulatory competition); Merritt B. Fox, Securities Disclosure in a Globalizing Market: Who Should Regulate Whom, 95 MICH. L. REV. 2498 (1997) (critiquing unmitigated competition); Stephen J. Choi \& Andrew T. Guzman, The Dangerous Extraterritoriality of American Sectrities Lmw, 17 Nw. J. INT'L L. \& BuS. 207 (1996) (advocating regulatory competition).

9 See Amir N. Licht, Genie in a Bottle? Assessing Managerial Opportunism in International Securities Transactions, 2000 CoLUM. Bus. L. REV. 51. 
This Article contributes to the literature by providing evidence for such an effect from an Israeli regulatory program aimed to lure Israeli issuers listed only on U.S. markets to list their stocks also on the Tel Aviv Stock Exchange ("TASE"). This is a particularly interesting case because U.S. listing by Israeli issuers is often brought as an example for corporate governance-improving piggybacking ${ }^{10}$ and because Israel is the second largest supplier of foreign stocks to U.S. markets, after Canada. In contrast, this Article argues - in a paraphrase on Brandeis' timeless maxim ${ }^{11}$-that foreign listing may sometimes help insiders and control persons to avoid the disinfecting sunlight of their home country securities law.

This case study provides a rare opportunity to isolate the alleged effect of managerial opportunism since it enables us to hold constant most of the regularly cited motivations for foreign listing. From the vantage point of most Israeli-U.S.-listed issuers, the differences between the domestic United States and Israeli securities regulation regimes and the United States regime for foreign issuers, to which they are already subject, refer to corporate governance issues. The staunch resistance from the Israeli business and financial sectors to any additional disclosure of this type is consistent with managerial reluctance to become subject to a more exacting corporate governance framework. The lessons this Article draws from this case study can inform policy makers in every country, however. Beyond the immediate context of foreign listing, this Article also contributes to the path dependence branch of the corporate governance literature in presenting evidence consistent with rent seeking and locked control models.12

The Article proceeds as follows. Section 2 reviews the managerial motivations for foreign listing. Section 3 describes the regulatory menu facing Israeli issuers in Israel and the United States.

10 See Asher Blass et al, Corporate Governance in an Emerging Market: The Case of Israel, 10 BANK AM. J. APPLIED CORP. FIN. 79 (1998); Coffee, sipra note 6, at 675; Rock, Securities Regulation as Lobster Trap, surpra note 6, at 1.

11 See LouIs D. BRandeis, OTher People's Money and How the Bankers Use IT 92 (1914).

12 See Lucian A. Bebchuk \& Mark J. Roe, A Theory of Path Dependence in Corporate Owmership and Govennance, 52 STAN. L REv. 127 (1999); Lucian Arye Bebchuk; A Rent-Protection Theory of Corporate Ownership and Control (Nat'l Bureau of Econ. Research Working Paper No. W7203, 1999), nunilable at http://papers.ssrn $\mathrm{com} / \mathrm{sol} 3 /$ papers.cfm?cfid $=79829 \&$ \&ftoken $=42986856 \&$ \&abstract_id $=203110$ (last visited Mar. 24, 2001). 
Section 4 provides a brief timeline of the dual listing project. Section 5 then discusses the conclusions that emerge from this case study. Section 6 concludes.

\section{MANAGERIAL MOTIVATIONS FOR FOREIGN LISTING}

Listing on a foreign stock market in order to credibly commit to a better legal regime is but one of several different motivations for making a foreign (single) or dual listing. Financial motivations are by far the more important reasons among them. ${ }^{13}$ Motivations in this rubric revolve around realizing international diversification and segmentation gains and increasing the stock's liquidity. ${ }^{14}$ As a result, firms can lower the expected return on equity and thus broaden the scope of feasible business projects. Another category of motivations includes other business goals, foremost among which is the desire to increase the issuer's visibility in the capital and product markets. ${ }^{15}$ Multinational and would-be multinational corporations also use foreign listing to establish an image of truly international firms. 16

Until recently, little attention has been paid to the role managerial opportunism may be playing in the decisions companies face regarding whether to make a foreign listing and the choice of particular destination markets. Most of the existing studies are largely oblivious to the problem, but this is now changing. For instance, Huddart et al. argue that stock exchanges competing for trading volume will engage in a "race for the top" whereunder disclosure requirements increase and trading costs fall.17 They base their entire model on a managerial opportunism assumption by examining

13 See Licht, Genie in a Bottle?, supra note 9, at 71-75.

14 See, e.g., Yakov Amihud \& Haim Mendelson, Liquidity and Asset Prices: Financial Management Implications, 17 FIN. MGMT. 5 (1988) (discussing liquidity gains in general); Vihang Errunza et al., Can the Gains from International Diversification be Achieved without Trading Abroad?, 54 J. FIN. 2075 (1999) (discussing diversification gains).

15 See H. Kent Baker, Why U.S. Companies List on the London, Frankfurt and Tokyo Stock Exchanges, 6 J. INT'L SEC. MARKETS 219, 221 (1992); H. Kent Baker et al, International Cross-Listing and Visibility 5-9 (Working Paper, 1998), available at http:/ / papers.ssrn.com/ sol3/papers.cfm?cfid=211807\&cftoken $=17422233 \&$ abstrc $t_{\ldots}$ id $=142287$ (last visited Mar. 24, 2001).

16 See Licht, Genie in a Bottle?, supra note 9, at 79-83.

17 Steven Huddart et al., Disclosure Requirements and Stock Exchange Listing Choice in an International Context, 26 J. ACCT. \& ECON. 237 (1999). 
"how public disclosure requirements affect listing decisions by rent-seeking corporate insiders." 18 In the spirit of the piggybacking paradigm, Fuerst argues that a stricter regulatory regime would allow firms to credibly convey information about their future prospects. 19 Fuerst accounts for managerial opportunism by modeling the adverse effects a stricter regime may have on managers due to increased exposure to securities litigation.20 Blass and Yafeh argue that Israeli high-quality innovative firms list in the United States to distinguish themselves from firms that issue stock back home.21

Elsewhere I reviewed the theoretical and empirical literature on the motivations for foreign listing and argued that company decision-makers are expected not to remain agnostic to legal duties pertaining to them individually.22 In certain situations, the effect on the agent could be significant while the effect on public shareholders is negligible - what Lucian Bebchuk has dubbed "significantly redistributive" issues.23 Examples of such issues include regulation of affiliated party transactions, disclosure of top executive remuneration on an individual basis, and opportunities to engage in insider trading with impunity. ${ }^{24}$

Although there exists evidence that the timing of (domestic) listing is affected by managerial interests, 25 arguments about managerial opportunism in foreign listing are inherently difficult to test empirically. This is due to several reasons. First, numerous motivations are likely to be at play simultaneously.26 Analyses based on stock price behavior can usually reflect only the aggre-

18 Id. at 237.

19 See Oren Fuerst, A Theoretical Analysis of the Investor Protection RegUllation ARgUMENT FOR Global Listing of STOCKS 3 (Int'l Center for Fin at Yale, Working Paper, 1998), available at http:// papers.ssrn.com/sol3/papers.efm ?cfid=799-11\&cftoken=34507821\&abstract_id=139599 (last visited Mar. 24, 2001).

20 See id.

21 See Asher Blass \& Yishay Yafeh, Vagnbond Shoes Longing to Stray: Why Foreign Firms List in the United States, 25 J. BANKING \& Fin. 555 (2001).

22 See Licht, Genie in a Bottle?, strpra note 9, at 88-104.

${ }_{23}$ See Lucian A. Bebchuk, Federalism and the Corporation: The Desirable Limils on State Competition in Corporate Law, 105 HARV. L REv. 1437, 1461 (1992).

24 See id. at 1461-67.

25 See Gwendolyn P. Webb, Evidence of Managerial Timing: The Case of Exchtmige Listings, 22 J. FIN. RES. 247 (1999).

26 See Licht, Genie in a Bottle?, stpra note 9, at 70-71. 
gate effect of the transaction. .27 In most cases, one would expect the positive effect resulting from financial and business reasons to override the potentially adverse effect of managerialism. Studies that tried to determine the level of informed trading following a foreign listing came up with conflicting findings. 28

Second, the research methodologies employed so far have been unsuitable for answering this question. In questionnaire-based surveys like Baker' ${ }^{29}$ or Fanto and Karmel's, ${ }^{30}$ which are otherwise informative as to corporate motivations, it would be practically impossible to gauge the role of management's own interests. By necessity, such questionnaires are addressed to top executives who are unlikely to openly state that they were motivated by personal interests.31 If they did, they would immediately expose themselves to personal lawsuits. Similarly, one cannot really expect to find as a stated rationale, for example, to restore management's peace of mind or to enable corporate executives more easily to trade on inside information, in a study like Chaplinsky and Ramchand's, ${ }^{32}$ that analyzed global offering disclosure statements.

Third, a research methodology like Saudagaran and Biddle's, ${ }^{33}$ which constructed disclosure level rankings in various ways, also cannot isolate those few disclosure items that may have a strong personal influence on corporate decision makers because they are only a small subset of the general disclosure regime. If a certain disclosure regime, in its entirety, is more burdensome than another (which is probably often the case), the particular effect of the personally-related items may be lost.

Finally, there exists a problem of selection bias: all the empirical studies cover companies that actually decided on and com-

27 See id. at 85.

28 See Amir N. Licht, Regulatory Arbitrage for Real: International Securities Regulation in a World of Interacting Securities Markets, 38 VA. J. INT'L L. 563, 599-601 (1998).

29 Baker, supra note 15, at 226; Baker et al., supra note 15, at 25-26.

30 See James A. Fanto \& Roberta S. Karmel, A Report on the Attitudles of Foreign Companies Regarding a U.S. Listing, 3 STAN. J. L. BUS. \& FIN. 51 (1997).

31 See, e.g., id. at 61 (discussing methods to obtain data from executives).

32 See Susan Chaplinsky \& Latha Ramchand, The Rationale for Global Equity Offerings (1996) (unpublished working paper, on file with author).

33 See Shahrokh M. Saudagaran \& Gary C. Biddle, Foreign Listing Locntion: A Study of MNCs and Stock Exchanges in Eight Countries, 26 J. INT'L BUS. STUD. 319 (1995). 
pleted a foreign listing. ${ }^{34}$ "They did not (and could not) cover all the companies whose management ever considered, but refrained from, effecting a foreign listing." 35

\section{THE REGULATORY MENU FOR ISRAELI ISSUERS}

Under traditional legal conventions, the legal regime governing a publicly traded company is a composite of the company law of its country of incorporation, the securities laws of all the countries where it is listed, and the listing rules of all the markets it is listed on. ${ }^{36}$ In a global economy with free flow of equity capital, Israeli entrepreneurs can incorporate under numerous national laws and companies can list their stock on dozens of stock exchanges. Israeli issuers' preferred jurisdiction for foreign listing is the United States, although several issuers are also listed on European markets.37 We can therefore limit the analysis of the regulatory menu facing potential issuers to the components included in Israeli and U.S. laws.

\subsection{Shareholding Structures}

As a backdrop for the legal menu, a note is in place with regard to typical Israeli shareholding structures. While U.S. and British public corporations tend to be widely-held, their Israeli counterparts tend to exhibit a European-like ownership structure.3s The

34 See Licht, Genie in a Bottle?, stipra note 9, at 103.

35 Id. Using a matched control sample would not solve this problem because such a sample needs to comprise companies that considered a foreign listing but rejected it altogether or a particular destination market.

36 The fundamental factor that engenders such composite legal regimes is the distinction between corporate law as private law and securities regulation as public law. In common law countries, the corporate law governing a country is the law of its country of incorporation, which has personal applicability. See RESTATEMENT (THIRD) OF FOREIGN RELATIONS LAW OF THE UNITED STATES § 213 (1987) (hereinafter RESTATEMENT) ("For purposes of international law, a corporation has the nationality of the state under the laws of which the corporation is organized."). Securities regulation, however, applies territorially. For a discussion of this legal complex, see Licht, Regulatory Arbitrage for Real, sipra note 28, at 61721.

37 See Telephone Interview with Kobbi Avramov, Head of Research Department, Tel-Aviv Stock Exchange (June 7, 2000).

3s See generally Rafael La Porta et al., Corporate Ownership Aroumd the World, 54 J. FnN. 471, 498-500 (1999) (providing information about various ownership structures). 
vast majority of issuers listed on the TASE have a controlling shareholder, which is either a family or the state. ${ }^{39}$ While Israeli securities law effectively prevents diversion from one-share-onevote capitalization, use of pyramids is rife, and a large part of TASE-listed companies are controlled by a handful of familycontrolled groups. ${ }^{40}$

Israeli issuers listed on U.S. markets are a mixed bag in terms of their shareholding structure as well as their size.41 Several Israeli issuers boast market capitalization in the billions of U.S. dollars, but there are also many medium and small size issuers. ${ }^{42}$ Many, but definitely not all, of these companies are "new economy" firms that operate in hi-tech areas and have U.S. venture capital ("VC") funds among their major shareholders. ${ }^{43}$ The more technology-oriented, VC-funded companies tend to have a larger portion of their equity capital publicly held compared with TASElisted companies.44 Even these companies, however, still have controlling shareholders and are not truly widely held. .5

\subsection{Company Law}

As of mid-2000, practically all Israeli publicly traded companies were incorporated under the Companies Ordinance, 1929, which was copied from the English Companies Act, 1929.46 Notwithstanding its old historical roots, legislative amendments it had undergone, and an extensive gloss added by courts' decision law allowed the Ordinance to provide robust foundations for a mod-

39 See id. at 500-02

40 See Kobi Avramov \& Yuval Zuk, Control Groups of Publicly Traded Companies, 214 HAHODESH BABURSA (Stock Exchange Monthly) 3 (1999).

41 The following details are culled from various sources as there is no official or public body that publishes data on these issuers. For an excellent review, see Edward B. Rock, Greenhorns, Yankees, and Cosmopolitans: Venture Capital, IPOs, Foreign Firms and U.S. Markets, 3 THEORETICAL INQUIRIES L. (forthcoming 2001).

42 For updated data, see http://analyst.co.il/anl/StockPoint/ (last visited Apr. 1, 2001) (listing issuers in Hebrew).

43 See Rock, Greenhorns, supra note 41, at 4.

44 See id. at 10, and informal discussions with Edward Rock. Rock.

45 See Rock, Greenhorns, supra note 41 , at 14 and informal discussions with Ed

46 See Shlomo Guberman, The Development of the Lnw in Israel: The First 50 Years, available at http://www.israel.org/mfa/go.asp?MFAH00y10 (last visited Mar. 24, 2001). 
ern, well-functioning company law. For the present purposes, suffice it to say that to a large extent, Israeli law looks very much like English or U.S. corporate law. It establishes similar governance institutions and imposes fiduciary duties of loyalty and care on directors, officers, and controlling parties. 77 Israeli merger law is relatively underdeveloped due to the paucity of merger transactions. On the other hand, both statutory and decision law are more stringent with regard to affiliated parties than U.S. law.48 Affiliated or interested party transactions were subject to special disclosure duties and non-interested approval procedures. ${ }^{49}$

Effective February 2000, the Companies Law, 5759-1999 replaced much of the old Ordinance. ${ }^{50}$ This is a modern piece of legislation, which adopted advanced corporate governance mechanisms, e.g., a tender offer regulatory regime designed after a model advanced by Bebchuk. 51 Except for a few issues, however, the new Law did not radically change the content of Israeli company law. Its treatment of insiders and controlling parties is somewhat more exacting, perhaps, than under the Ordinance.

It should be noted that starting in the late 1990s, Israeli entrepreneurs began incorporating under the Delaware General Corporation Law. ${ }^{52}$ This trend is gaining momentum. ${ }^{53}$ Different sources have estimated that during the years 1999-2000, around ninety percent of new start-up companies were incorporated outside of Is-

47 See, e.g., Companies Law 5759-1999, \$\$ 252-54 (Aryeh Greenfield, A.G. Publications trans., June 1999) (providing duties of care and loyalty).

45 For instance, Israeli Law sets forth elaborate procedures for approving transactions between public corporations and affiliated parties. See Companies Law 5759-1999, \$§ 270-75 (Aryeh Greenfield, A.G. Publications trans, June 1999). For a review of the law under the Ordinance, see Zohar Goshen, Controlling Corporate Agency Costs: A United States-Israel: Comparative View, 6 Cardozo J. INT'L \& COMP. L. 99 (1998).

49 See id at 109-10.

so Companies Law 5759-1999 (Aryeh Greenfield, A.G. Publications trans., June 1999).

51 See, e.g., Lucian A. Bebchuk, Toward Undistorted Choice and Equal Treatment in Corporate Takeovers, 98 HARV. L REv. 1695 (1985).

52 See Yaakov Scheinin \& Yossi Hollander, The Macro Picture: Working Paper Toward the Conference "Israel's Future Industries" at The Israel Democracy Institute, Tel Aviv 13 (May 26, 2000) (unpublished working paper, on file with author).

53 See id. 
rael, mostly in the United States. ${ }^{54}$ Among the reasons mentioned for this trend are burdensome tax implications for corporate transactions and restrictions on controlling shareholders under the new Companies Law. 55

\subsection{Securities Regulation}

Israeli securities regulation is based on the Securities Law, 5728-1968 and regulations thereunder.56 The regime is based on Anglo-American concepts and specific rules, which, at bottom, make it quite similar to the securities regulation regime under the United States Securities Acts. Both legislative and decision laws impose extensive disclosure duties, prohibit manipulation, fraud, and insider trading, and rely on U.S. legal concepts like materiality. ${ }^{57}$ Israeli law differs from U.S. federal law in that it sometimes proscribes duties that in the United States are found in stock exchange listing rules, e.g., immediate disclosure of material events.58

Israeli issuers that opt for listing on a U.S. national market become subject to the regulatory regime applicable to foreign private issuers ${ }^{59}$ and can report using Form 20-F.60 This U.S. foreign issuer

54 See Itamar Levin, Doron Kohavi, CPA: The Number of Hi-Tech Companies Incorporating Overseas Instead of in Israel Has Doubled, GLOBES, Jan. 3, 2001; Scheinin \& Hollander, supra note 52, at 12.

55 See Stella Korin-Lieber, Just Like in America, GlOBES, Feb. 20-21, 2000. 2000).

56 Securities Law 5728-1968 (Aryeh Greenfield, A.G. Publications trans., April

57 See, e.g., C.A. 3520/90 Baranowitz v. Securities Authority, 46(2) P.D. 818 (applying materiality test to disclosure duty); Crim. A. 4675/97 Rozow v. State of Israel (not yet published) (applying materiality test to insider trading).

58 See Securities Regulations (periodical and intermediate reports), 5740-1970, $\S 36$.

59 The term "foreign private issuer" is defined in Rule 3b-4(c) under the Securities Exchange Act of 1934, 17 C.F.R. $\S 240.3 b-4(2000)$. This status is granted to entities incorporated outside the United States unless more than half of the corporation's shareholders are located in the United States, and the entity's principal business activities are located in the United States. The definition was amended in September 2000, inter alia, with regard to determining the location of shareholders. Thanks to Howell Jackson for these details.

60 In September 2000, the SEC adopted a complete revision of Form 20-F in order to align it with the international disclosure standards of the International Organization of Securities Commissions ("IOSCO"). This is not a relaxation of the disclosure requirements applicable to foreign issuers, however, and the key financial statement requirements have not changed. See EDWARD F. GREENE ET AL., U.S. 
regime differs from the regime applicable to domestic (U.S.) issuers in several significant points, as detailed below. The crucial point is that similar differences exist in comparison with the Israeli regime.

The most significant differences concern disclosure of conflict of interests. Form 20-F permits foreign private issuers to disclose aggregate remuneration and aggregate options to purchase securities, unless the issuer discloses these data for individually named directors and officers. ${ }^{61}$ Foreign issuers are further exempted from disclosing data concerning material transactions with officers, directors, and control persons, unless the issuer makes such disclosure.62 According to Loss and Seligman's authoritative treatise, "[ $t]$ hese requirements significantly compromise the more demanding conflict of interest requirements found in Items 402 to 404 or Regulation S-K."63

Form 20-F requires foreign issuers to disclose the names of persons known to them as owning more than ten percent of the issuer's voting securities and the total amount of voting securities owned by the officers and directors as a group, without naming them.64 In contrast, the threshold for U.S. (and Israeli) issuers is five percent, and issuers must disclose individual holdings of their officers and directors. 65

While foreign issuers' financial statements must be substantially similar to those filed by domestic issuers, the former can, in certain circumstances, avoid the requirement to disclose business segment information. ${ }^{66}$ Lowenstein, among others, considers this

REGULATION OF THE INTERNATIONAL SECURTIES AND DERIVATIVES MARKETS SA1-1-2 (5th ed. 2000).

Note that by incorporating under U.S. corporate law, Israeli entrepreneurs lose the option to list as a foreign private issuer, so there is a trade-off between an arguably more lenient corporate law and a stricter securities regulation regime.

61 Form 20-F, 5 Fed. Sec L Rep. (CCH) I 29,701 (1993).

62 See id.

63 See Louts Loss \& Joel Seligman, 2 SeCURTIES Regulation 769 (1991).

64 Form 20-F, 5 Fed. Sec L. Rep. (CCH) I 29,701 (1993).

65 See 17 CF.R. \$229.403(a) (2000) (providing American issuers); Securities Regulations (Periodical and Intermediate Reports), 5740-1970, $\$ 24$ (providing Israeli issuers).

66 LOSS \& SELIGMAN, stqura note 63, at 769. 
duty an important corporate governance tool and identifies additional accounting-related issues with a similar effect. 67

Rule $3 a-12^{68}$ exempts foreign private issuers from several duties with regard to proxy statements under Section 14 of the Exchange Act. As a result, the sensitive voting mechanism of these issuers, inasmuch as proxies are involved, is not subject to the same disclosure regime that applies to domestic U.S. issuers.

Rule 3a-12 further exempts foreign private issuers from Section 16 of the Exchange Act, namely, from the prohibition on short sales and short-swing profits by corporate insiders. 69 While these insiders remain subject to disclosure duties regarding their shareholdings under Section 13 and to the general anti-fraud prohibition under Rule $10 \mathrm{~b}-5,70$ the exemption from Section 16's short-swing sales prohibition does allow them more room to trade on insider information.

Finally, foreign issuers using Form $20-\mathrm{F}$ can file an annual report within six months after the end of the fiscal year covered, while domestic issuers must include financial statements that are within 135 days of the filing date.71

\section{THE DuAl Listing PROJeCT}

\subsection{The Roots}

The roots of the dual listing project go back to 1983, when the TASE was closed down for three weeks in the wake of the worst financial crash in Israel's history.72 In 1993, the market started to gather steam again, but in 1994 it was hit by another crash. ${ }^{73}$ With public confidence completely lost, the market became dormant until 1999. Consequently, the fast growing high technology sector was unable to tap the TASE for the funds it needed during the

67 See Louis Lowenstein, Financial Transparency and Corporate Governance: You Manage What You Measure, 96 COLUM L. REv. 1335, 1346 (1996).

6817 C.F.R. $\$ 240.3 a-12-3(b)(2000)$.

6917 C.F.R $\$ 240.3 a-12-3(2000)$.

7017 C.F.R. $\$ 240.10 b-5$ (2000).

71 Form 20-F, 5 Fed. Sec. L. Rep. (CCH) $\|$ 29,701 (1993).

72 See MARSHALl SARNAT ET AL, THE STOCK EXCHANGE AND THE INVESTMENT IN SECURITIES 41-45 (Marshall Sarnat \& June Dilevsky, eds., 2d. ed. 1999).

73 Id. 
1990s. As a VC industry was also largely undeveloped at that time, start-up companies began seeking funding in the United States. With the United States just coming out of a recession, the timing was perfect, and, with Silicon Valley VC fund managers on their boards, the road to NASDAQ was the natural one to take.74

It seems that in the mid-1990s, TASE officials realized that if they continued losing this business, they would lose "the entire shop." In response, they started floating the idea of a fast track dual listing of U.S.-listed Israeli companies ${ }^{75}$ - what later came to be called "automatic dual listing." The dual listed firms were supposed to jump start the local market and provide the necessary volume for maintaining the local financial sector alive.76

\subsection{The Brodett Committee}

In February 1998, a new Israel Securities Authority ("ISA") Chairwoman nominated an expert committee (the "Brodett Committee") to examine whether exemptions should be given to dual listing of securities that are already listed overseas. 7 The Committee narrowed down its analysis to the national U.S. markets, in light of their dominance, as the destination for Israeli foreign listings. ${ }^{78}$ It compared in detail the legal and accounting regimes under Israeli law with those applicable to foreign issuers under U.S. federal securities law and markets' listing rules.79 The Committee also surveyed managers of seventy U.S.-listed Israeli firms and received twenty-five responses. ${ }^{80}$

Although the Brodett Committee was authorized to "examine possibilities," its working assumption was that the situation was anomalous, unacceptable, and likely to lead to irreversible harm to Israel's high-tech sector and capital market.81 The Committee thus adopted the TASE's analysis that things must be changed, and

74 Rock, Greenhorns, supra note 41, at 10-15.

75 See Merav Arlozorov, TASE: Dunl Listing Will Contribute at Lanst Another USS100M to Trading Volumes, GLOBES, Jan. 8-9, 1997.

76 See id.

77 See IsRael Securties AuthortT, Commtrtee Report on Dual listing of SECURIIIES 3 (1998) [hereinafter BRODEIT REPORT].

78 See id. at 4.

79 See id. at 30, app. 9.

so See id. app. 3.

s1 See id. at 7. 
quickly.82 The Committee further expressed hope that bringing "higher league" players to the local market would improve market discipline.

The Committee Report is based on several noteworthy findings:

1. The legal and accounting regime applicable to American issuers - based primarily on Form $10-\mathrm{K}$ periodical disclosure under the Exchange Act-is substantially equivalent to the Israeli one in terms of the investor protection it provides and therefore can be relied on for regulating dual listed securities.83

2. In contrast, the U.S. regime applicable to foreign issuers based primarily on Form $20-\mathrm{F}-$ is inferior to the Israeli regime and the Form 10-K regime. 84

3. Israeli issuers in the United States use Form 20-F, but most of them supplement their reports with voluntary, 10-K-like disclosure of business data. ${ }^{85}$

4. Surveyed officers ranked the following subjects as requiring relaxation of the Israeli disclosure regime:

a) Special disclosure requirements in a prospectus. 86

b) Timing of business results disclosure.

c) Immediate reporting of pending negotiations.

d) Disclosure about transactions with interested and controlling parties.

e) Disclosure about private placements of securities.

The Committee strongly recommended adopting a special dual listing arrangement for securities listed on national U.S. markets. ${ }^{87}$ It rejected, however, the idea of relying on issuers' Form 20-F reports, notwithstanding the few voluntary supplements. ${ }^{88}$ Instead,

82 See id. at 14.

83 See BRODETT REPORT supra note 77, at 25, app. 8 .

84 See id. at 21.

85 See id.

86 These requirements include specification of main clients, product segmentation, benefits to interested parties, and names of main shareholders. Note, however, that these requirements are largely identical to public offerings by U.S. issuers registered under Section 5 of the Securities Act and using Form S-1 thereunder.

87 See BRODETT REPORT, supra note 77, at 15.

88 See id. at 21. 
it recommended to require issuers to upgrade their reporting to the more demanding regime applicable to U.S. issuers. 99 The Committee opined that only the latter standard is suitable for investor protection in Israel and would prevent discrimination against local issuers. 90

\subsection{Implementation}

When the Report was released in September 1998, its recommendations were pioneering in terms of the regulatory paradigm they reflected, namely, the unilateral recognition of a foreign securities regulation regime. ${ }^{91}$ Notwithstanding an initial warm welcome, the industry was not truly happy with the recommendations, as they did not call for automatic dual listing.92 As the implementation of recommendations got repeatedly delayed, the ISA came under growing attacks from the TASE on the one hand, speaking on behalf of the financial sector, and from the Public Companies Association ("PCA") on the other, representing the issuers.93 Anything short of automatic dual listing, they argued in public and private fora, would render the project stillborn.9- Their main concern was the additional disclosure duties dealing with interested and controlling parties. ${ }^{95}$

To complicate things further, the new Companies Law was to go into effect in February 2000 and foreign-listed Israeli companies demanded to be exempted from duties they were not subject to heretofore. ${ }^{96}$ Industry representatives argued during discussions in the Knesset (the Israeli parliament) that the foreign laws are suf-

\section{9 see id.}

9o See id. at 25.

91 In July 1999, Belgium surpassed Israel in adopting such a regulatory strategy, intending to assist NASDAQ in its competition with other European stock markets. For a review and analysis of the Belgian project, see Amir N. Licht, Stock Exchange Mobility, Unilateral Recognition, and the Privatization of Securities Regulntion, 41 VA. J. INT'L L (forthcoming 2001).

92 See Yoram Gavison, Bronfeld: Viability of Crpital Market is in Dmger without Approval of Dual Listing, HAARETZ, Dec. 31, 1999.

93 See id.

94 See id.

95 See Motti Bassok, Public Companies Association: Without Drastic Change in Capital Market Hi-Tech Companies Will Flee Israel, HAARETz, Feb. 2, 2000; Gavison, supra note 92; Stella Korin-Lieber, Doing Us a Favor, GLobEs, Nov. 30-Dec. 1, 1999.

96 Committee Discussion in the Knesset, minutes not publicly available. 
ficient for protecting Israeli public shareholders. ${ }^{97}$ They also complained that the new law is generally hostile to controlling shareholders and would drive them to incorporate in Delawaresomething that had already begun. 98

The confrontation reached its peak in mid-February 2000, under the shadow of intensifying competition to the TASE. ${ }^{99}$ In a meeting called by the Minister of Finance, Mr. Brodett reversed his position and sided with the TASE and the PCA's demand for automatic dual listing. ${ }^{100}$ The Minister ordered "maximum relaxation" in drafting the dual listing law. ${ }^{101}$ The ISA read the writing on the wall and backed away from its original requirement of $10-\mathrm{K}$ like periodical reporting. At that point, people at the ISA were willing to accept 20-F-based reporting but still insisted on disclosure regarding interested parties. Continuing pressure from the TASE and prominent business persons forced the ISA to cave in in this respect also. Independently, but related to the dual listing project, the ISA promoted other legislative reforms generally applicable to all issuers.102 Their effect was to iron out several differences between the Israeli and U.S. securities laws.

97 Id.

98 See Levin, supra note 54; Scheinin \& Hollander, supra note 542, at 12.

99 At that time, NASDAQ's Chairman visited Israel and it was announced that NASDAQ intends to open an extension in Tel Aviv. Earlier that year, NASDAQ announced its plan to start trading in four leading NASDAQ-listed lsraeli securities. The immediate threat to the TASE was evident. See, e.g., Boaz Levi, Capital Has No Passport, HaARETZ, Feb. 16, 2000 (illustrating that future capital markets will not be bound by national borders); Keren Zuriel \& Zeev Klein, Tightening Connections between NASDAQ and Israeli Companies Listed on it to be Examined, GLOBES, Feb. 12-13, 2000 (announcing the plans of the Israeli Prime Minister and the head of NASDAQ to tighten the relationship between the NASDAQ, TASE, and Israeli firms listed on the NASDAQ).

100 See Merav Arlozorov, David Brodett Changed His Mind, HAARETZ, Feb. 15, 2000; Korin-Lieber, supra note 55.

101 See Korin-Lieber, supra note 55.

102 These issues included abolishing disclosure of pending negotiations, exemption from prospectus in employee securities offerings, exemptions and relaxation regarding interested parties transactions, etc. See Securities Law 5728. 1968, amend. 20 (Aryeh Greenfield, A.G. Publications trans., April 2000); Companies Regulations (Relaxations regarding Transactions with Interested Parties), 5760-2000. Special further exemptions were made to foreign listed companies in order to prevent putting them under conflicting requirements that stem from lsraeli company law on the one hand and foreign securities laws on the other hand. See Companies Regulations, 5760-2000. 
In July 2000, the Knesset adopted an agreed amendment that allows Israeli issuers listed on national U.S. markets to list their stocks on the TASE based entirely on disclosures they make overseas under U.S. law or voluntarily. ${ }^{103}$ The ISA retains its regulatory jurisdiction over such issuers to request additional information, 104 but it is understood that this authority is reserved for exceptional circumstances. Necessary regulations were adopted in October 2000 and by early 2001, eight companies had already been listed on the TASE under the new arrangement.105

\section{DISCUSSION}

The case of the Israeli dual listing project provides a rare opportunity to isolate as much as possible the effect of managerial interests on the foreign listing decision, on corporate decisionmaking in general, and on the content of corporate governance rules. This is because the factual context of the project is unique in comparison with the numerous cross-sectional studies of foreign listings and even company-specific case studies, e.g., of DaimlerBenz's listing on the NYSE.106 While in most cases making a foreign listing is one giant leap for the issuer, the kind of dual listing envisaged for the project should not be more than one small step. Managerial interests feature highly among the factors that affect taking this step.

As a general matter, making a foreign listing entails considerable transaction costs. The primary market transaction of the listing itself is costly, ${ }^{107}$ and on-going disclosure is also costly when-

103 See Securities Law 5760-2000, amend. 21 (Aryeh Greenfield, A.G. Publications trans., 2000).

104 See Securities Law 5728-1968, as amended, \$35.24 (Aryeh Greenfield, A.G. Publications trans., 2000).

105 See Yoram Gavinson, Paradigm - Eighth Dual Listed Company, HAaretz, Feb. 14, 2001.

106 See Dennis E Logue \& James K. Seward, Challenges to Corporate Governance: Anatomy Of a Governance Transformation: The Case of Daimler-Bent, 62 LAW \& CONTEMP. Probs. 87 (1999); see also Lee H. Radebaugh et al,, Foreign Stock Exchange Listings: A Case Study of Daimler-Benz, 6 J. INT'L Fin. MGMr. \& ACcr. 158 (1995).

107 See Howell Jackson \& Eric Pan, Regulatory Competition in International Securities Markets: Evidence from Europe in 19993 (June 9, 2000) (unpublished manuscript, on file with author) (surveying costs of alternative primary market transactions). 
foreign market. The putative benefits of the foreign listing hopefully compensate for these additional costs. What makes the present case unique is the fact that for U.S.-listed Israeli issuers, these costs are mostly sunk costs, because these issuers had already paid for underwriting, accounting, and legal services, and had already adjusted to reporting under the foreign regime.

Suppose, arguendo, that dual listing on the TASE would have zero benefits for the issuer. This is a very unrealistic assumption: the TASE now has a modern trading system, which allows it to charge highly competitive trading fees. It operates in a different time zone, 108 and clearance and settlement of trades on it are completed on a $\mathrm{T}+1$ basis. 109 Finally, in most U.S.-listed Israeli issuers the vast majority of employees are Israeli residents, a great deal (often a majority) of shareholders are Israelis, and oftentimes - especially in non-high-tech issuers-their customer base is also largely Israeli.110 As a result, dual listing on the TASE is likely to increase liquidity and have a positive effect on share value.

To be sure, absent a special arrangement, listing on the TASE would entail costs associated with complying with the Israeli disclosure regime since such listing would be deemed a public offering or security. Indeed, such listing could be just as "foreign," even for a U.S.-listed Israeli issuer, as it would have to bear substantial compliance costs in order to prepare financial statements in Hebrew and according to Israeli GAAP. The dual listing project was supposed to eliminate these costs by permitting issuers to use

108 Cf. Ian Domowitz et al., International Cross-Listing and Order Flow Migration: Evidence from an Emerging Market, 53 J. FiN. 2001, 2002-03 (1998) (noting, however, that despite the difference in time zone, the trading hours overlap within an hour of those of the United States market).

109 See TASE, http://www.tase.co.il/html2/pub/clearing/p_introd.htm (describing the TASE clearing house) (last visited Mar. 24, 2001).

110 It is difficult to know the national identity or other details with regard to shareholders who hold less than ten percent of the issuer's voting shares. Set Form 20-F, 5 Fed. Sec. L. Rep. (CCH) I 29,701 (1993). The text therefore reflects common knowledge among Israeli's market professionals. For indirect evidence, see Rock, Greenhorns, supra note 41, tbl.5 (providing details about principal shareholders in large U.S. listed Israeli issuers); Ronit Harel Ben-Zeev, Activity in Isrneli Stocks in the U.S. in 1998, 210 HAHODESH BABURSA [STOCK EXCHANGE MONTHLY] 3 (1999) (arguing that trading activity in most U.S.-listed lsraeli stocks is low or medium because American institutional investors are not attracted to them). 
their U.S. disclosure documents as a basis for compliance with Israeli securities regulation. ${ }^{111}$

Recall that the Brodett Committee originally recommended that dual listed issuers be required to enhance their reporting from a 20-F-based to a 10-K-like regime.112 To assess the compliance cost implications of this recommendation it is useful to distinguish between three categories of disclosure subjects: financial disclosure (comprising mainly of financial statements), business disclosure (regarding, e.g., competition and line-of-business), and corporate governance disclosure. As regards financial disclosure, both the Committee and the ISA found that most U.S.-listed Israeli issuers already comply, voluntarily, with the majority of disclosure items required under Form 10-K but not under Form 20-F.113 Enhancing current disclosure with additional financial information would not significantly change the regulatory burden borne by dual listed companies. A similar outcome would obtain with regard to other business-related disclosure. As a result of the aforementioned reform in Israeli securities law, listing on the TASE would not have created difficulties in terms of disclosing pending negotiations, summary business results, etc.

The last category is corporate governance disclosure, and the picture here is fundamentally different. As already mentioned, U.S. general securities law calls for several disclosure items that go to the root of the agency problem but are not required under the U.S. foreign issuer regime.114 Israeli securities law includes substantially the same requirements.115 For this reason, the Brodett Committee believed that complying with Form 10-K could satisfy the legislative purpose of investor protection as interpreted by Is-

111 See supra Section 4.2 .

112 See BRODETT REPORT, supra note 77, at 21.

113 These items include a description of dependence on a particular client or group of clients, updated aggregate orders for current and previous years, and identification of activity markets and competitors, when material. Israeli issuers reporting under Israeli GAAP also happen to provide line-of-business disclosure, which is indirectly called for under Form 20-F. A disclosure item required under Form 10-K but not under Form 20-F, which is not regularly disclosed by Israeli issuers, is a reporting of sales by product breakdown. See Letter from Tal EvenZahav, Israel Securities Authority, to Amir Licht (June 7, 2000) (on file with author).

114 See supra Section 3.3.

115 See supra Sections 3.2, 3.3. 
raeli law while not imposing excessive compliance costs due to lsraeli formalities. ${ }^{116}$ The TASE and issuer representatives, however, staunchly and vocally resisted even an iota of additional disclosure and eventually prevailed. 117

The developments in the dual listing project thus suggest that managerial interests probably played a significant role in forming the final version of the Israeli amendment, which adopted a watered-down dual listing regime. ${ }^{118}$ This interpretation is consistent with path dependence models that are based on rent seeking and locked control structures.119 Before concluding that this indeed was the case, consider two possible counter-arguments.

First, the initiative for a dual listing exemption and the continuing pressure towards the project's completion came primarily from the TASE, with the PCA generally taking the back seat. One could thus argue that competition between stock exchanges has led to the final legal outcome. This is a correct, but inconclusive, argument. Stock exchanges that vie for listings need to persuade management to choose them. To succeed, they are likely to internalize managerial interests if they thought that such interests would be decisive. The reluctance of stock exchanges in the United States in the late 1980s to agree on a one-share-one-vote rule provides a vivid example for stock exchanges guided by managerial interests. ${ }^{120}$ Indeed, when the SEC promulgated Rule 19c-4, which would have prevented dual class common stock recapitalization, it was the Business Roundtable-a business interest group-that challenged the Rule in court and led to its annulment. ${ }^{121}$

Second, one could argue that disclosure requirements under both the U.S. and the Israeli laws are excessive and that institutional investors - who are the dominant players in today's equity

116 See BRODETT REPORT, supra note 77, at 25.

117 See supra Section 4.3.

118 See BRODETT REPORT, supra note 77, app. 3.

119 See Bebchuk, supra note 12; Bebchuk \& Roe, supra note 12.

120 See, e.g., Marcel Kahan, Some Problems with Stock Exchange-Based Securities Regulation: A Comment on Mahoney, The Exchange as Regulator, 83 VA. L. REV. 1509, 1514-18 (1997) (arguing that exchanges designing and regulating securities regulations are subject to incentive and enforcement problems).

${ }_{121}$ Business Roundtable v. SEC, 905 F.2d 406 (D.C. Cir. 1990). 
markets ${ }^{122}$ - could have demanded such corporate governance disclosure. The fact that Israeli issuers make voluntary business disclosure would thus indicate that they respond to market demand for information, when such demand exists. This argument too is inconclusive, however. To begin, it is subject to the objection that corporate governance disclosure is a "significantly redistributive issue" 123 and thus unlikely to be set optimally by market forces.

More importantly, there may be positive value to government regulation of financial markets compared with contractual commitments. ${ }^{124}$ Evidence indeed shows that institutional investors are interested in regulating disclosure of this sort. Recall that Regulation S-K (but not Form 20-F) requires individual disclosure of remuneration and option plans for top corporate directors and officers. ${ }^{225}$ Recently, the International Corporate Governance Network, an international body of institutional investors, adopted an "enhanced" version of the OECD's Principles of Corporate Governance, ${ }^{126}$ in which it calls for disclosure of remuneration breakdown of individual directors and top executives.127

Until February 2000, Israeli regulations under the Securities Law allowed issuers to disclose remuneration information on an aggregated basis, but a 1992 amendment to the old Companies Ordinance required publicly traded corporations to provide an individual remuneration breakdown.128 The new Companies Law, however, does not have a parallel provision, such that by February

122 See Michael Bradley et al., The Purposes and Accomntability of the Corporation in Contemporary Society: Corporate Governance at a Crossronds, 62 LAw \& Contem. Probs. 9, 18 (1999).

123 See Bebchuk, supra note 23, at 1461.

124 See Rafael La Porta et al., Investor Protection and Corporate Governunce, 58 J. FIN. ECON. 3, 21 (2000).

125 See supra notes $63-68$ and accompanying text.

126 See ORGanZaTION FOR ECONOMIC CO-OPERATION AND DEVELOPMEMT ("OECD"), OECD PRINCIPLES OF CORPORATE GovernanCE, OECD Doc SG/CG(99)5 2 (1999), availnble at http://www.oecd.org/daf/governance/ principles.htm (last visited Feb. 22, 2001).

127 See InIERNATIONAL CORPORATE GOVERNANCE NETWORK, STATEMIEST ON Global CoRporate GovernanCe Principles, July 9, 1999 at 7, muilable at http://www.thecorporatelibrary.com/docs/globalcorpgov.htm (last visited Feb. 22, 2001).

128 COMPANIES ORDINANCE, \& 123A (1983) (providing the official translation of the British 1929 Ordinance). 
2000, Israel could have been left without regulation of this issue. Davis Global Advisors, Inc., an institutional investor consulting firm specializing in comparative corporate governance, voiced concern about this possibility. ${ }^{129}$ After the ISA was informed of these concerns, ${ }^{130}$ it moved quickly to introduce into the Securities Regulations language similar to that used in the about-to-expire Ordinance. Davis Global responded with satisfaction. ${ }^{131}$

To recap, from the vantage point of most Israeli U.S.-listed issuers, corporate governance disclosure is the main difference between the domestic U.S. (and Israeli) regime and the foreign issuer regime to which they are already subject. The staunch resistance from the business and financial sectors to any additional disclosure is consistent with, and is probably due to, managerial reluctance to become subject to a more exacting corporate governance framework. By listing, and remaining listed, only in the American market officers and controlling persons of Israeli issuers were able to take advantage of its more lenient disclosure regime. As we have seen, this leniency of the foreign issuer disclosure regime is not benign and is commonly interpreted as inferiority. In the regulatory competition literature the debate is simplistically cast in terms of a "race for the top" versus a "race for the bottom." In this framework, making a foreign listing in the U.S. is considered as piggybacking on a superior regulatory system, namely, "a piggyback race for the top."132 As this article shows, however, the case of Israeli issuers provides evidence consistent with the contrary conjecture. If there was any piggybacking going on in this case, then it was for the bottom.

129 See Secret Pay Ballot, Global Proxy WatCH, Jan. 21, 2000, at 1; Letter from Stephen Davis, Davis Global Advisors, to Amir Licht (January 17, 2000) (on file with author).

130 Letter from Amir Licht to Miri Katz, ISA Chairperson (Jan. 25, 2000) (on file with author).

131 See Eleventh Hour, Global Proxy Watch, Feb. 4, 2000, at 2. An odd outcome of this development is that Israeli issuers now do not need to provide individual remuneration disclosure because the Securities Law and regulations thereunder apply territorially while the Companies Ordinance had personal, international application. It must be noted, however, that U.S.-listed Israeli issuers used to ignore the provisions of the Ordinance that were directed to publicly traded companies on the (wrong) assumption that they apply only to TASE-listed issuers.

132 See supra text accompanying notes 6-8. 


\section{CONCLUSION}

The present study contributes to several currently open debates. The story of the dual listing project adds to the body of evidence suggesting that managerial opportunism is a significant factor in decision-making processes in public corporations. In particular, this study provides evidence directly relevant to the growing phenomenon of foreign listing. This study also sheds light on the role managerial opportunism plays in legislative processes of corporate governance-related rules. With this said, one must not conclude that managers are only interested in taking advantage of public shareholders, nor that foreign listings are necessarily fraud schemes in disguise, nor that corporate governance must be heavily regulated under a single international umbrella. Such interpretations would be caricatures of the arguments advanced here. More than anything else, this study attests to the need for more empirical evidence on these important issues. 
